\title{
BARTIN VE YÖRESİ AĞIZLARINDAKİ LEHÇE TABAKALAŞMASI
}

\author{
ZEYNEP KORKMAZ
}

§ 1. Türkoloji Dergisi'nin 1-inci sayısında yayımlanan Bartın ve Yöresi Ağızları Üzerine ${ }^{1}$ adlı makalemizde, bu bölgenin ağız bakımından taşıdığı önemli durumu belirtirken, bu durumun bölgenin etnik yapısı ile ilgili olması gerektiğine de işâret etmiştik. Çünkü, B a rtın ve yöresi'nin, bir yandan Anadolu ağızlarında görülen genel ve ortak özelliklere sahip olmak yahut A n a d o l u'nun kimi bölgecikleri ile özel ağız bağlantıları kurmak suretiyle Oğuz lehçeleri gurubuna girecek bir ağız bölgesi niteliğini taşırken, bir yandan daAnadolu'daki dil kurallarının dışına çıkarak, Kıpçak lehçeleri grubundan gelen özelliklere sahip olması ve bu durumun ortaya çıkardığı lehçe tabakalaşması, ancak bölgenin etnik yapısında beliren karışmalar ile açılanabilmektedir.

İşte eldeki yazıda, bundan önceki yazıda karanlık kalmış olan ve aydınlatılmasının özel bir araştırmaya bağlı bulunduğuna işâret ettiğimiz ${ }^{2}$ noktalar üzerinde durarak, Bartın ve yöresi ağılarındaki lehçe tabakalaşması'nı ele alacağız. Böylece, hem Bartın ve yöresi ağızlarının yapısını oluşturan etnik gelişmeler incelenmiş, hem de dil araştırmalarının ortaya koyduğu şaşmaz gerçekler, bir kez de tarih ve arşiv vesikalarının verdiği bilgilere dayanılarak değerlendirilmiş olacaktır.

\section{Bölgedeki Lehçe Tabakalaşması}

$\S 2$. B a r tın ve y ö r e s i ağızlarındaki belli başlı dil özellikleri, bu özelliklerin temsil ettiği biribirinden ayrı ağız veya lehçe kollları bakımından ele alınacak olursa, bölgede başlıca üç ayrı lehçe ve ağız tabakasının bulunduğu tesbit edilir. Bunlar: 1) Oğuz, 2) Türkmen, 3) Kıpçak tabakalarıdır.

1 Türkoloji Dergisi, C.I, S.I, sah. 103-141

${ }^{2}$ Bk. not I'de adı geçen yazı sah. 2-5. 
Bartın ağzının önseste ünsüz tonlulașması, ünlü incelme ve daral maları, ses düşme ve türemeleri, $r$ düșmesi, aynı sesi üst üste tekrarlayan $r^{\prime} l i$ hecelerden birinin yutulması, ünlü ve ünsüzler arasındaki değişim ve benzeşme, -duḳ/-dük 1-inci geçmiş zaman birinci şahıs çokluk ekindeki yuvarlaklık ${ }^{3}$ gibi, onu kimi zaman yazı dili, fakat çoklukla öteki An adolu a ğı zları ile birleştiren özellikleri ${ }^{4}$, elbette $\mathrm{O} \breve{g} \mathrm{uz}$ Türkçesinden gelme özelliklerdir. Bunlar bölgenin dil yapısındaki temel tabakayı kurarlar. Kelime ve hece başlarında yuvarlak ünlüler önündeki $g_{-}>\dot{g}_{-}, k->k$ - değişimleri ile, bu değişimlerin geliştirmiş olduğu orta boğumlanmalı o, u ünlülerinin bulunuşu ${ }^{5}$, hal kipi ekindeki düzleşmé, belirli kelimelerin iik hecelerinde görülen ve Türkçedeki "aslî uzunluklar" konusu ile ilgili bulunan uzun ünlüler, vurgulu hecelerdeki ünlü uzamaları, kelime ve cümle sonlarina gelen hecelerin birçok hallerde yüksek tonlu ve uzatılarak söylenmesinden doğan ahenkli konuşma tarzi ${ }^{7}$ Abu Hayyan'ın Türkmen lehçesi için verdiği $b>v$ değişiminden oluşmuş -van / -ven, -vuz/-vüz birinci şahıs bildirme bağı (cevher fiili) eklerinin ${ }^{8}$ daha ileri bir ses değișimine uğramış şekilleri olan -yın >-yin, -yuz/-yüz eklerini devam ettiregelmesi ${ }^{9}$ gibi kimi özellikler ile de, bu bölge $\mathrm{Oğuz}$ Türkçesi içinde daha özel bir kişiliğe bürünerek Anadolu Türkmen ağızları ve Orta-Asya Türkmen Lehçesi ile birleşmekte; dolayısiyle de bir Türkmen lehçe tabakasına dayanmaktadır ${ }^{10}$.

3 Kaşgarî bu şeklin açıklamasını yaparken $\mathrm{Oğuz} \mathrm{lehçesine} \mathrm{özgü} \mathrm{bir} \mathrm{şekil} \mathrm{olarak} \mathrm{da} \mathrm{kay-}$ dediyor. Bk. B. Atalay, Divanu Lûgat it-Türk Tercümesi, C.II, sah. 61-62. -duk/-dük I-inci şahıs ekinin genel durumu ve öteki şahıslardaki şekilleri ile karşılaştırmak için 9-uncu notta verilen makalemize bk.

4 Bu özellikler için not I'de gösterilen makalemize, -r'yi üst üste tekrarlayan hecelerdeki haplologie olayının Oğuzca'ya has olduğu noktasında, M. Kaşgarî, Divanu Lûgat-it-Türk, C.II, sah. 35'e bk.

${ }^{5}$ Bk. Z. Korkmaz, Bartın ve Yöresi Ağızları Üzerine, §§ 2,8,11; Nevşehir ve Yöresi Ağızları, Ankara Üniv. DTCF. yayınları: 142, Türk Dili ve Edebiyatı Araştırmaları Enstitüsü: I, Ankara TTK. Basm. 1963, §§ 10-13; 61, 74 ve sah. 74; Güney-Batı Anadolu Ağızları: Ses Bilgisi, Ankara Üniv. DTCF. yayınları: 114, Türk Dili ve Edebiyatı serisi: 11, Ankara TTK. Basm. 1956, §§ 10,12,41.

${ }^{6}$ Bk. Bartın ve Yöresi Ağızları Üzerine, §. 2.

7 Bartın ve yöresi ağızlarının yukarndan beri sayılagelen bu özellikleri için not I'de verilen makalenin ilgili paragraflarma bk.

${ }^{8}$ Bk. Abu Hayyan, Kitabï'l-idrak li lisanü'l-etrak, A. Caferoğlu yayın, İstanbul, 1931, sah. 161 .

9 Bu sekillerin tarihî gelismesi için bk. Z, Korkmaz, -van/-ven, -vuz/-vüz Bildirme Bağı (cevher füli) Eklerinin Anadolu Ağızlarındaki Kalıntıları, Türk Dili Araştırmalan Yıllığı, 1964, (basılmakta).

${ }_{10}$ Yukandaki açıklamalardan da anlaşılacağı üzere, biz bu yazıda Oğuz ve Türkmen deyimlerini etnik birer terim olarak değil, Oğuz grubu içindeki ağız ve lehçe ayrılıklarım belirtecek birer dil terimi olarak kullanmaktayı. Bilindiği gibi, birtek etnik grubun iki ayrı 
Bölge, kurallı olarak devam ettiregeldiği $\tilde{n}>y, g>v$ v.b. ses değişimleri bakımından ise, bundan önseki makalemizde belirttiğimiz üzere ${ }^{11}$, Anadolu ağızlarındaki genel dil yapısından uzaklaşarak 13, 14-üncü yüzyıllar K 1 p ç a k Türk çe si ile ortaklaşan bir ağız niteliği taşımaktadır. Demek oluyor ki, B a rtın ve yöresi a ğızları, bu üç ayrı lehçe ve ağız tabakasının karışmasından oluşmuştur. Ancak, bu karışmadan sonraki gelişmeler sırasında, bölgeyi öteki A n a d o 1 u ağızları ile ortaklaştıran $\mathrm{Oğu} \mathrm{z} \mathrm{tabakası} \mathrm{nisbeten} \mathrm{daha} \mathrm{zayıf} \mathrm{kalmış;}$ buna karşılık Türkmen ve Kıpçak tabakalarının karışıp kaynaşmasından oluşmuş şekiller daha hâkim duruma geçerek, bölgeye, kendisini öteki Anadolu ağızlarından belirli şekilde ayıran özel bir kişilik ve dil yapısı kazandırmıştır.

Şimdi, B a r t 1 n ve y ö res i ağızlarının oluşmasındaki tabakalaşmaların hangi şartlar altında ve ne şekildə ortaya çıkmış olduğunu göstermek üzere, bölgenin tarihî devirlerine doğru bir göz atalım:

kolunu gösteren $\mathrm{Oğuz} \mathrm{ve} \mathrm{Türkmen} \mathrm{sözleri,} \mathrm{tarihî} \mathrm{araştırmalarda} \mathrm{anlamdaş} \mathrm{deyimler} \mathrm{olarak}$ kullanıldıkları gibi, $\mathrm{Oğuz} \mathrm{ve} \mathrm{Türkmen} \mathrm{adı} \mathrm{altındaki} \mathrm{zümrelerin} \mathrm{yaşayıs} \mathrm{tarzlarından} \mathrm{ileri} \mathrm{gelen}$ ayrılık dolayısiyle ayn kavramlan göstermek üzere de kullanılmışlardır. (Bu husustaki görüşler için bk. Z. V. Togan; Umumi Türk Tarihine Giriş, İstanbul, 1946, sah. 187). Z.V. Togan, Kaşgarî ve Birunî’deki kayıtlara dayanarak Oğuz sözünün göçebe hayata sadakatı ifade ettiğini, Türkmen sözünün ise daha çok medenî kavimlere komşu olarak oturan ve ziraatle de uğraşan yarı yerleşik Oğuzlara verilmiş olduğunu belirtiyor. Oğuz ve Türkmen unsurlarının Anadoluya yerleşmesin den sonraki durum şüphesiz bu anlayış ve nitelendirmeye paralel gitmemektedir. Oğuz genel deyimi içinde daha özel bir kavramı karşılayan Türkmen sözü, $A$ nadolu'da özellikle 15-inci yäzyıldan sonraki çağlarda, yerleşik hayata geçmiş Oğuzlara ve Batı Anadolu'nun göçebe Yörüklerine karşı, Orta ve Doğu Anadolu'daki göçebe veya yarı göçebe Oğuz kollarına verilmiş bir addır ( $O$ ğuz, Türkmen ve Yörük deyimlerinin bu bakımdan gösterdikleri anlam ayrlıkları için bk. F.Sümer, Avşarlara Dair, Fuad Köprülü Armağan, DTCF. yayın, İstanbul, Osman Yalçm Mtb. 1953, sah. 453-454; Osmanlı Devrinde Anadolu'da Kayılar, Belleten C. XII. S. 47, Temmuz 1948, sah. 584, not 30; Z. Korkmaz, Güney-Batı Anadolu Ağızları: Sesbilgisi. sah. XXXVII-XL). Biz burada Oğuz ve Türkmen deyimlerini, bu adlan taşıyan $\mathrm{Oğuz} \mathrm{etnik} \mathrm{unsurları} \mathrm{arasındaki} \mathrm{önemli} \mathrm{ağız} \mathrm{ayrılığını} \mathrm{belirtmek} \mathrm{için} \mathrm{kullan-}$ dık. Oğuzca, Anadolu'da, Anadolu ağızların kısmen yazı dili, kısmen de biribirleri ile birleştiren, yerleşik hayata geçmiş en eski $\mathrm{Oğuz}$ unsurlarının diline dayanan, istikrarh, durulmuş bir alt tabaka niteliğindedir. Anadolu'nun türlü bölgelerindeki asıl yerli ağızları, genel olarak Oğuzca dediğimiz bu alt tabaka kurar. Türkmence ise, bu yerli alt tabakaya oranla epey değişiklik gösteren ve Anadolu'ya geliş tarihleri bakımından da daha yeni olan $\mathrm{O}$ ğuz kollarının dilidir ve bir üst tabaka durumundadır. Bunların Anadolu içinde uzun bir süre göçebe veya yarı göçebe olarak yaşamış olmaları, ağız özelliklerindeki ayrılığın korunmasında başhıca etken olmuştur. A n a dol u Türkmenleri'nin ağızları birçok noktalarda Orta-Asya Türkmencesi ile de birleşmektedir.

$"$ Bk. Türkoloji Dergisi, C.I, S. I, sah. 105-110, § 3 . 


\section{Bartın'ın Tarihî Devirlerdeki İskân Durumu}

$\S 3$. Kelime yapısı "sular ilâhesi" anlamındaki Parthenius kelimesinden geldiği bildirilen ${ }^{12}$ Bartın'in Türk-İ̀slâm devrinden önceki tarihi oldukça eskidir. Bitinya ve Paphlagonia tarihlerine kadar iner ${ }^{13}$. Ancak, Bartın'ın Anadolu'nun türkleşmesinden önceki devirleri bizim konumuzun sınırı dışında kaldığından, burada $B$ a r tı $n$ ve yöresi, yalnız XI. yüzyıldan sonraki Türk-İslâm devri içinde ele alınacaktır.

Bartın, arkeoloji buluntularının da ortaya koyduğu şekilde, Türk-İslâm devrinden önce çok eski bir yerleşme bölģesi olarak karşımıza çıtığı halde, buranın Anadolu Türk tarihi içinde müstakil bir ilçe olarak gelişmesi pek eski sayılmaz. Doğrudan Doğruya Bartın içinde yaptığımız bölge araştırmalarının verdiği sonuçlar, bu ilçenin kuruluşunu ve Bartın içindeki yerleşme tarihini üç dört yüzyıldan daha geriye götüremiyor. İlgililerce, Bartın'da bugünkü Cumhuriyet Meydanı'nın yerinde bulunan en eski mezarh̆̆ın kaldırılması sırasında gözden geçirilen mezar taşlarının 300 yıldan daha önceye çıkmadığı tesbit edilmiştir. Bartın'da Türk devrini temsil eden eski eserler de yoktur. Bartın'ın en eski aileleri kendi şecerelerinin nereden geldiğini bilememektedirler. Bölgenin yerleşme tarihi ile ilgilenen aydın yerliler, ilçe halkının buraya birkaç yüzyıl önce dolaydaki köylerden, Safranbolu, Eflâni ve Daday bölgelerinden göç etmek suretiyle yerleştiklerini söylemektedirler. Bu durumu birkaç göbekten beri Bartın'lı olarak bilinen ailelerin şeceresi üzerinde yaptığımız özel araştırmalar da doğrulamıştır. Yerinde yapılan incelemeler ile, kuruluşunda daha eski devirlerine inemediğimiz Bartın için, bazı tarihî kaynakların verdiği bilgiler ile biraz daha gerilere gitmek mümkündür. Ancak, eldeki imkânlar çerçevesinde bu da 15-inci yüzyıldan daha gerilere gidememektedir.

14-üncü yüzyıl seyyahlarından İbni Battuta, seyahatnamesinde ${ }^{14}$, Bolu, Safranbolu, Kastamoniyye, Sinop şehir ve kaleleri üzerine bilgi verdiği halde, Bartın'dan hiç bahsetmemiştir. Bu bakımdan 14-üncü yüzyılda Bartın'in köy, bucak veya kasaba hâlinde var olduğu konusunda bir bilgimiz

12 Bk. A. Gökoğlu, Paphlagonia, Kastamonu Doğrusöz Mtb. 1952, sah. 28.

${ }^{13}$ Bu konuda bilgi almak için bk. Ch. Texier, Küçük-Asya Tarihi, C. III, sah. 155 A. Gökoğlu, not 12'de göst. y.; Kemal Samancıŏ̆lu, Iktisad ve Ticaret Bakımından Bartın, Bartın Ticaret ve Sanayi Odası Yayın, 1942, sah. 119-137: Bartın ve Civarı Haklında Tarihî Bilgiler.

14 Ibni Battuta (Mütercimi: M. Şerif): Tuhfetü'n-nezzâr fi Garaibü'l-emsâr ve Acâibü'lesfâr: Seyahatname-i Ibni Battuta, İstanbul, Matbaa-i Âmire, 1333-1335, 448 sah. 
yoktur. 15-inci yüzyılın tarihî kaynaklarında da doğrudan doğruya Bartın'ın adı geçmez. Fatih Sultan Mehmed'in karadan ve denizden kuşattırmak suretiyle Cenevizliler elinden almış olduğu Amasra fethinden bahseden Mehmed Neşrî, fetih olayını anlatırken: "Hünkâr Amasra'nın üzerine konup, oturup, gemiler dahi gelip Amasra'nın limanma girdiler" 15 demektedir. Öteki bazı tarihî kaynakların da ele almış o!d $ı$ kları bu fetih olayında, Fatih'in Amasra'nın üst kısmında kamp kurmuş o'd ığu yer, Bartın-Amasra yolu üzerinde ve Amasra'ya girilen sırtın başında bulunan bugünkü Asker-suyu semtidir. Alayazı ve Hzzrreli'nden geçerek Bolu'ya gelen Fatih'in ${ }^{16}$ Amasra'ya geçişi şüphesiz Bartın yolu ile olmuştur. Ancak, genel olarak o devirde Bartın'ın meskûn bir yer olmayıp pazar yeri olarak kullanılan ticarî bir bölge hâlinde var olduğu kabul edilmektedir ${ }^{17}$. Bu konuda yapılan incelemelerden, Amasra'nın alınışından sonraki devrede, Bartın'ın daha çok Amasra tarihine bağlı olarak geliştiği anlaşılmaktadır. Cenevizliler elinde bulunan Amasra' da kuvvetli bir denizcilik ve ticaret hayatı devam etmekte idi. Amasra'nın Osmanlılar eline geçmesind «n sonra, burada kısmen sarsılmış olan ticaret durumu ağırlığını bir pazar yeri hâlinde bulunan Bartın'a aktarmıştır ${ }^{18}$. $\mathrm{Bu}$ durum da oranın bir yerleşme merkezi hâlinde gelişmesinde her halde etki yapmiş olmalıdır. Nitekim 16-ıncı yüzyıl vergi tahrir defterlerinde Bartın ya bu ad ile, yahut da ileride yeniden ele alınacağı üzere "Oniki Divan" nahiyesi adı altında (Bartın nam-ı diğer Oniki Divan) Bolu sancağına bağh pek çok köyü bulun?n bir yerleşme bölgesi olarak tesbit edilmektedir. Yalnız, Bartın bu defterlerin kimisinde "nahiye-i Oniki Divan", kimisinde de "kaza-i Oniki Divan" adı altında kaydedilmiştir. Hattâ, H. 935 (M. 1528) tarihini taşıyan Bolu Livası Kanunu'nun 26-ıncı maddesinde bu yer Oniki Divan kazası olarak yazılı olduğu halde aynı kanunun 7 ve 8-inci maddelerin-

${ }^{15}$ Mevlâna Mehmed Neşrî (yayın: Franz Taeschner), Kitab-ı Cihannüma, C.I, Berlin Akademi yayım, O. Harrassowitz 1951, sah. 190.

${ }^{16}$ Bk. Kemal Paşazade (Ahmed Şemsüddin), Al-i Osman Tarihi, Cüz VII, Fatih Ktb. no: 4205, yp. 92; Selâhaddin Tansel, Osmanlı Kaynaklarına göre Fatih Sultan Mehmed'in Siyasi ve Askeri Faaliyeti, TTK. yaymlarndan XI, seri no: 4, TTK. Basm. 1953, sah. 251; I.H, Uzunçarşılı, Osmanlı Tarihi, II. Cilt. İstanbulun Fethinden Kanuni Sultan Süeleymanın Ölümüne Kadar, TTK. yayınlarından XIII, Seri no: 1672, TTK. Basm. Ankara 1949, sah. 48.

17 Bk. Kemal Samancıoğlu, Íktisat ve Ticaret Bakımından Bartın, Bartın Ticaret ve Sanayi Odası yayın 1942, sah. 145.

18 Bartın'ın geçmiş yüzyıllardaki ticaret ve iktisat durumu için, not 17'de göst. e. sah. 11-11̣2 arasındaki bölümlere, Bartın ırmağında yükletilen Mısır gemileri için Evliya Celebi Seyahatnamesi, C. II, Dersaadet İdam mtb. 1314, sah. 71'e bk. 
de nahiye-i Oniki Divan olarak geçmektedir ${ }^{19}$. Bu durum Oniki Divan'm o zıman bir ilçe mi, yoksa bir bucak olarak mı bulunduğu konusunda kararsızlık doğurmakta ise de, yine defterlerdeki bu konuda verilen kayıtların çokluk ve ilçenin gelişme durumlarını gözönünde bulundurarak, Bartın'ın 16-ıncı yüzyıl başında henüz bir bucak olarak var olduğunu kabul etmekteteyiz. Bartın'ı sırf bir ilçe merkezi olarak ele aldığımızda iskân ve kuruluş tarihini eldeki vesikalar ile 16. yüzyıl başlarında bırakmak zorunda kalacağız. Ancak, Bartın ilçesini yöresi, yani kendisine bağlı bucak ve köyleri ile birlikte daha geniş bir bölge olarak ele aldığımızda, bu bölgeyi kuran etnik unsurlar bakımından tesbit edeceğimiz gelişme tarihi, bölgeyi şüphesiz daha eski bir devre kadar götürebilecek niteliktedir. 1337 (1921) yılından sonra Zonguldak iline bağlanmış olan Bartın, yukarıdaki açıklamalardan da anlaşılacağı üzere bundan önce Bolu sancağına bağhı bir ilçe idi. Bartın'ı doğrudan doğruya veya dolayısiyle ele almış bulunan bazı eserler, ilçenin ilkin bir voyvodalık, daha sonra Kasıamonu'ya bağhı bir kadılık iken, 1284 (1867) teşkilâtı ile ilçe hâline getirilip önce Bolu'ya, 1337'den bu yana da Zonguldak'a bağlandığını kaydederler ${ }^{20}$. Ancak, biraz önce söz konusu ettiğimiz kaṇunlar ve arazi vergi tahrir defterleri, Bartın’ı 16-ıneı yüzyıldan beri Bolu livasına bağh bir ilçe veya bucak olarak gösterdiklerine göre, yukarıda Bartın'1 1284 teşkilâtından sonra Bolu'ya bağlanmış gösterme şeklindeki kayıt doğru olmamak gerekir. Bartın'ın Kastamonu'ya bağlanma durumuna gelince: Tapu Kadastro Genel Müdürlüğü Arşivi'nde bulunan 16-ıncı yüzyıla ait arazi vergi tahrîr defterlerinin hiç birinde ${ }^{21}$ Bartın yer almamaktadır. Bu duruma göre Bartın'ın Kastamonu'ya bağlılığı bu yüzyıldan daha önceye düşmek gerekir. Bartın ve y ö r e s i idarî bakımdan 16-ıncı yüzyıldan bu yana ve Zonguldak'a bağlanma tarihinden önceki birkaç yüzyıllık uzun bir devre içinde Bolu'ya bağlı bulunduğu halde, ondan önceki ilgisi doğrudan doğruya Kastamonu bölgesi iledir. Çünkü, o devirlerde gerek Bolu bölgesine giren toprakların kısmen Kastamonu ve yöresi içinde bulunması ve gerek yukarıda ilçenin iskân durumu dolayısiyle belirttiğimiz üzere Bartın ve dolaylarına yerleşmiş olan halkın Safranbolu, Eflâni, Ulus ve Daday bölgelerinden gelmiş olması, bizi, ister istemez Bartın'ın

19 Bk. Ömer Lütfi Barkan, 15 ve 16-ıncı Astrlarda Osmanlı Imparatorluğunda Zirai Ekonominin Hukukî ve Malî Esasları, İstanbul Üniv. Edebiyat Fakültesi, Türkiyat Enstitüsü yaym, C. I: Kanunlar, İstanbul, Burhaneddin mtb. 1943' Sah. 29-32 arasındaki Bolu Livast Kanunu'nun (Aslı-: İst. Başbakanlık Devlet Arşivi, no: 881) 7,8 ve 26-ıncı maddeleri.

${ }^{20}$ Bk. A. Gökoğlu, Paphlagonia (Kastamonu, Sinop, Çankırı, Safranbolu, Bartın, Bolu, Gerede, Mudurnu, İskilip, Bafra, Alaçam ve civarı), Kastamonu Doğrusöz mtb. 1952, sah.28

21 Bk. Defter-i Mufassal-ı Kastamonu, no: 143, 176 ve 200. 
incelenmesinde Kastamonu tarihine bağlamaktadır. Yalnız, Kastamonu tarihine girmeden önce burada bir noktayı daha belirtelim:

Eldeki en eski arazi vergi tahrir defterleri ile vakıf defterlerinin incelenmesi, bu bölgenin iskân tarihi bakımından kısmen Yıldırım Bayezid, II. Murad ve Fatih Sultan Mehmed devirlerinde geliştiğine işâret etmektedir. Ankara Tapu Kadastro Genel Müdürlüğü Arşivi'ndeki 547 sayılı Defter-i Evkaf-ı Liva-yı Bolu bu hususta bazı kıymetli kayıtlar taşımaktadır. Defterin 157-188-inci sahifeleri arasında yer alan Evkaf-ı Nahiye-i Oniki Divan bölümünde yer yer vakıf köylerinin yahut bir kısım köylerde türlü kimselere vakıf suretiyle verilmiş olan topraklarm öşür ve öşürden muaf tutulma durumları belirtilirken, bu yerlerin Sultan Bayezid-i Hüdavendigâr, Sultan Murad II veya Sultan Mehmed Han beratları ile verilmiş bulunduğuna işâret edilmektedir. Bunlardan çoğu da Bayezid $\mathrm{Han}$ vakfıdır. Hele Amasra'nın Türk halkı ile iskânı, doğrudan doğruya Fatih devrine ve Fatih vakfına dayanmaktadır. Bartın ve yöresi ağızları üzerine yayınladığımız birinci makalemizde Amasra'nın Türkler eline geçmesinden sonra, F atih'in, buranın Türk ve müslüman olmayan ahalisini İstanbul'a aktarıp, yerine Kastamonu ile Safranbolu arasındaki Eflâni kalesi sakinlerini getirip yerleştirdiğini tarihî kaynakların kaydetmekte olduğuna işâret etmiştik ${ }^{22}$. Amasra yerlileri arasında yaptığımız incelemeler bizi bu konuda daha geniş sonuçlara ulaştırmıştır. Gerek kökleri belli en eski ailelerin ifâdesinden, gerek incelediğimiz en eski tapu kayıtlarından anlaşılmaktadır ki, Fatih, Sinop kalesini almadan önce ele geçirdiği Amasra'yı Türk halkı ile iskân edebilmek için buraya getirdiği Eflâni kalesi sakinlerinden başka, ordusunda bulunan BoluKastamonu arasındaki bölgeden gelme Safranbolu, Daday, Azdavay ve Eflâni'li kimseleri de azad ederek, Amasra sınırlanı içindeki belirli yerleri ekip biçmeleri için kendilerine harp ganaimi olarak vermiş veya vakfetmiştir ${ }^{23}$. Bu sebeple Amasra halkı uzun bir süre vergiden bile muaf tutulmuştur. Sonradan kız alıp vermekten başlayarak türlü sesyal münasebetler ve gelişmeler dolayısiyle Amasra'ya yakın köyleı halkından gelip yerleşenler de olmuştur. Pek az

${ }^{22}$ Bartın ve Yöresi Ağızları Üzerine, Türkoloji Dergisi, C. I, S. I, sah. 110, § 4; Aynca I.H.Uzunçarşılı, Osmanlı Tarihi, C. II, sah. 49.

${ }^{23}$ Ornek olarak Eyice, A lemdarlar, Sancaktarlar, Bayraktarlar, Hacı Nuriler, Terziler, Tuğlacılar, Kalaf a toğulları aileleri gösterilebilir. Bunlardan Ey i c e o ğ u 11 a r 1 kendi aile şecerelerinin Belgrad seferinde Fatih'in sancaktarlığın vapmıs olan Eflâni'li Eyice Baba'ya kadar uzandığını, Alemdarlar ise aile kuruỉuşlarını Fatih devrine kadar gidişinden başka, Eflâni ve Safranbolu ile ilgili olduğunu da nakletmektedirler. 
sayıda olmak üzere daha yakın zamanlarda Rumeli ve Balkan muhacirIeri gelerek, Amasra'nın içinde ve köylerinde yurt tutmuşlardır. Ancak, "muhacir" diye nitelendirdiğimiz bu sonuncular, bizim araştırma konumuz içindeki etki ve fonksiyonları bakımından önemsiz durumdadırlar.

Bartın köyleri üzerindeki arşiv incelemeleri, bölgeyi kısmen de Candar oğulları devrindeki gelişmeye bağlamaktadır. Yukarıda sözü geçen 547 sayılı Bolu Livası Evkaf Defteri'nin 157 b sahifesinde Karye-i Afşar Divanı'nda Hamza Fakih'in elinde bulunan mülk için: "Hamza Fakih tasarruf edegeldiği mülkdür, İs fendiy ar Bey kadim mülk arasında satın alup vakfetmiş", şeklindeki kayıt dikkati çekmektedir. Bu yazının devamında da aynı mülk için sonradan "Bayezid-i Hüdavendigâr'ın hükm-i hümâyun verdiği" yazılıdır. Aynı defterin 169-uncu sahifesinde, kendisine Bayezid-i Hüdavendigâr tarafından vakfedilmiş olan, Künye köyünden Seyyid Fakih elindeki onbeş mudluk toprağın "İsfendiyar Bey zamanında Hüseyin Naib mülkiyetinde bulunduğu" yazılıdır. Karaköy'deki "Yusufçu yeri" denilen toprak da İsfendiyar Bey'ile oğlu Kasım Bey vakfi olarak gösterilmiştir. Arandıkça örnekler daha da artırılabilmektedir. Bütün bu durumlar, Bartın'ı bazı köyleri dolayısiyle Osmanlılar'dan önceki devirde doğrudan doğruya Candaroğulları topraklarına bağlayan açı delillerdir. 1418 tarihli Arapça bir vakfiyeden de ${ }^{24}$ bugünkü Kutlubey, Tuzcular, Hamza ve Gecen köyleri topraklarını içine alan ve o zaman Af̧sar Divanı'nın Eflâgun

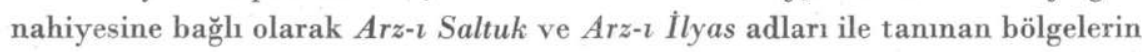
Sendel b. Alâeddin ve Ali b. Hacı Bey adlı kimselerce, "âlim, fâzıl ve âmil-i kâmil" diye nitelendirilen Tarak b. Ömer b. Gecen'e vakfedilmiş olduğu ve bu yerlerin "Gecen vakfı" diye bilindiği anlaşılmaktadır. Şimdiki Eflâni'nin yerinde bulunan Eflâgun nahiyesinin o zaman Candar oğulları toprakları içine giren bir bölge olduğu hattâ buranın Emir Şemseddin Yaman Candar'ın idare merkezliğini bile yaptığı hesaba katılırsa, bugün Bartın yöresinde bulunan bir kısım toprakların o zaman doğrudan doğruya Candaroğulları arazisi içinde bulunduğu dolayısiyle de Kastamonu ve yöresinin tarihî gelişmesi içinde ele alınmak gerektiği kendiliğinden ortaya çıkar.

Yukarıdaki bilgilere - eklenecek başka bir nokta da, Bartın'ın öteki adı olan Oniki Divan deyimi üzerinde toplanmaktadır. Tapu Kadastro Genel Müdürlüğü Arşivi'ndeki 1051 tarihli ve 35 sayılı Defter-i Mufassal-ı Bolu'da

${ }^{24}$ Vakfiyenin Türkçeye aktarılmış metni için bk. K. S a m ancıoğlu, yuk. göst. e., sah. 146. 
bu ilçe hem Bartın hem de Oniki Divan adlariyle kaydedilmiştir. Fakat, gerek 547 sayılı Evkaf Defteri'nde, gerek 123 sayılı Defter-i Mensuhat-ı Mufassal-ı Bolu'da (sah. 92 ve öt.) ve 935 (1528) tarihli Bolu Livası Kanunu'nda, Bartın, yalnız nahiye-i Oniki Divan adı ile yer almıștır. Evliy a Çelebi, Bolu dolaylarından bahsederken: "Divan ta'bir ettikleri de, Selçukîlerden Sultan Alâeddin, asrında Bolu beyi iken bu dağları feth ettikçe istimâlât vermek için divan edüp kûs çaldurduğı yerlerdir ki, hâlâ divan lâfziyle ta'bir olunur. Yedi adet nahiyelerdir. Ahalisi tagî ve bagî âdemler olup ve lisan ve lehçeleri ber veçh-j âtî bir nebze zikrolunur" ${ }^{25}$ şeklinde bir açıklama yapmaktadır. Evliya Çelebi bu açıklaması ile, divan deyimi altındaki adlandırmaların Selçuklular devrine kadar uzanan eskiliğine işâret etmektedir. Her ne kadar Evliya Çelebi, Bolu bölgesinde Oniki Divan adını zikretmemiş ise de, bu bucak yakarıda sıraladığımız kanun ve dofterlerin tarihlerinden anlaşlacağı üzere, Evliya Çelebi'den bir yüzyıl önce daha 16-ıneı yüzyıl başından beri bilinmektedir. Evliya Çelebi'nin Oniki Divan'dan bahsetmemiş olması, artık bu devirde Bartın adının umumîleşmiş olması ile izah edilebilir. Nitekim seyahatnamede bu yer "Bartın Kal'ası" diye (C.II,s.71) geçmektedir. Evliya Çelebi'nin divan deyimini almış bu yerler üzerindeki açıklamaları karşısında; eğer Oniki Divan adı Bartın'a Selçuklular'dan sonraki devirde verilmiş bir ad değil ise, eskiliği ve iskân durumu Selçuklular devrine kadar uzanabiliyor demektir. Ayrıca defterlerd, bu gibi divan deyimi altındaki adlandırmalara Bartın'a bağlı köy adlarında da rastlanmaktadır: karye-i Afşar Di-

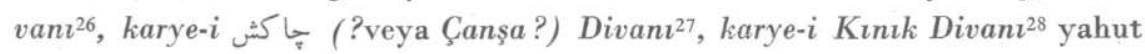

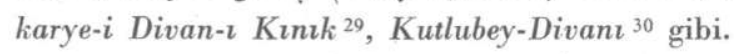

Yukarıdaki açıklamalardan anlaşılmaktadır ki, Bartın ve yöresi Osmanlılar devrine kadar siyâsî ve idarî yönden Kastamonu ve yöresine bağlı bir bölge olmuştur. Bu sebeple bölgedeki lehçe tabakalaşmasını meydana getiren etnik gelişmolerin, Kastamonu tarihi içine giren olaylar arasından süzülüp çıkarılması gerekmektedir.

25 Cilt II, sah. 175.

${ }^{26}$ Defter no: 547 , sah. $157 \mathrm{~b}, 160 \mathrm{~b}$.

27 Aynı defter sah. 164b.

28 Göster. defter sah. 166b.

${ }^{29}$ Defter-i Mufassalı Bolu no: 35, sah. 121.

30 821 (1418) tarihli Arapça Vakfiye. Türkçeye aktarılmış metni için bk. K. S a man cıoğlu, Yuk. göst. e., sah. 146. 


\section{Kastamonu Tarihi içinde Bartın ve Yöresi}

§ 4. 14-üncü yüzyıl coğrafyacısı al-Umarî'nin (Şihabaddîn Abu'labbas Ahmed b. Fadlallah al-Umarî) Masâlik al-absar fi mamalik al-amsar adlı eserinde, kırk şehir ve bir o kadar da kal'ası bulunan önemli bir bëlge ve beylik diye nitelendirdiği Kastamonu ve yöresinde, Türk-İslâm çağı içinde Osmanlılar'dan önce aşağıdaki beylikler kurulmuștur:

1) Danişmendliler,

2) Çobanlar,

3) Candaroğulları

$\S$ 5. Danişmendliler devri: Sultan Melikşah'ın emirlerinden Emir Danişmend ${ }^{31}$ eliyle kurulan, şekil ve hukuk bakımlarından A n a d olu SelçukS u lt a n lı ğ I 'na bağhı bulunan Danişmendli Emirliği, bilindiği üzere. S el ç u k sultanları arasındaki anlaşmazlıklardan yararlanarak 12-inci yüzyıl ortalarında yer ve gụ̧̈ bakımından Anadolu'nun en önemli cmirliği hâline gelmişti ${ }^{32}$. Bu emirlik, Danişmend Gazînnin oğullarından Emir Gazî zamanunda Furat'tan Sakarya menbalarma kadar uzanan Orta ve Kuzey Anadolu'ya yayılmış, böylece Malatya, Elbistan, Kayseri, Ankara ve Çankırı' dan başka Kastamonu bölgesini de ele geçirmiş bulunuyordu ${ }^{33}$. Bu konudaki tarihî vesikaların incelenmesi Kastamonu'nun 1127-1169 yılları arasında Bizanslılar ile Danişmendliler arasında birkaç defa el değiştirdiğini göstermektedir ${ }^{34}$. Kastamonu zaman zaman Selçuklu-Danişmendli çarpışmalarına da sahne olmuştur. Bugün Kastamonu, Araç ve Daday bölgelerinde Danişmendli emirlerine atfedilen bazı türbeler bile vardır ${ }^{35}$. Fakat bölgede bu emirlik devrine ait tarihî bir eser bulunamamıştır. Danişmendli emirliğinin Analolu'nun fethind, ve türkleşmesinde Selçuklular'a paralel olarak büyük rol oyaadığı şüphesizdir. Fakat bu emirliğin asıl faaliyet alamı Malatya, Amasya ve Suvas bölgeleri olduğundan, Bizans ve Komnenoslar ile Danişmendliler arasında bir sınır bölgesi kuran Kastamonu ve yöresinin

${ }^{31}$ Emir Danişmend'in ash, Anadolu'ya gelişi v.b. için bk. M ükrimin H alil Y in a n ę, Türkiye Tarihi: Selçuklular Devri, Cüz I sah. 74, 80, 82, 89, 103.

${ }^{32}$ D a nişmendli Emirli ğ i’nin siyasî hayatındaki gelişmeler iẹin bk. M ük r imin Halil Yinaņ,, Danişmendliler md., İslâm Ansiklopedisi, C. II, sah. 468-476; P. Wittek, Menteşe Beyliği, sah. 7 ve öt.

${ }^{33}$ Bk. İslâm Ansiklopedisi, C. III, sah. 470.

${ }^{34}$ Bk. M.H. Y i n a n ç, yuk. göst. Danișmendliler md.'si; M e h m e d B e h ç e t, Kastamonu Assar-ı Kadîmesi, sah. 22; T a lât M ü m t a z Y a m a n, Kastamonu Tarihi, sah. 72-77.

${ }^{35}$ Talât M ümtaz Y a man, Kastamonu Tarihi, sah. 77. 
bu emirlik zamanında ne dereceye kadar türkleşmiş olduğu ve Danişmendli T ü r k m e n unsurunun bu bölgede o zaman ne dereceye kadar yer aldığı konusunda, eldeki tarihî kaynaklar bize kesin bir yargı verdirecek durumda değildir. Ancak, bugün Kastamonu'da Cide'ye bağhı bir Danışman köyü ile, Bolu ilçelerine bağh Danışmantlar ve Danışmant, Zonguidak'ın Ereğli ilçesine bağlı iki Danişmentli köyünün bulunması ${ }^{36}$, Kastamonu, Zonguldak, Bolu üçgeni arasındaki bölgeye bu devirde olmasa bile, Danişmendli'lerin yıkılıp dağılmasından sonraki devirlerde bir kısım Danişmendli Türkmen zümresinin gelmiş olduğunu istidlâl ettirmektedir. Bilindiği gibi, Danişmendli devletinin yıkılı̧ı üzerine, Danişmendli adında bir ulus meydana getiren Türkmenler çeşitli boy ve oymaklar halinde Anadolu'nun türlü bölgelerine dağılarak orada da köyler kurmuşlar ve kısmen yerleşik hayata geçmişlerdir ${ }^{37}$. Ancak, böyle daha sonraki devirlerde de olsa, Kastamonu tarihinde Bartın ve yöresi ile Danişmendli Türkmenleri arasında yakın ilgili bulunduğunu gösterecek deliller yoktur.

\section{Kastamonu ve Yöresinde Cobanlar}

§ 6. Danişmendli emirleri ile Selçuklu sultanları arasında süregelen çarpışmalar, sonunda, Danişmendli'lere ait yerlerin Selçuk sultanlarından II. Kılıç Arslan tarafından Selçuk egemenliği altında toplanması ile sona ermiştir. Bu arada Kastamonu ve yöresi de Selçuklular eline geçmiştir. Ancak, II. Kılı̨ Arslan'ın memleketini oğulları arasında paylaştırmasından sonra doğan iç anlaşmazlıklar, bundan Bizans'ın yararlanmasına; Kastamonu ve Bolu taraflarından başlayarak Selçuklu Anadolusunun Amasya'ya doğru zorlanmasına yol açmiştı. İstanbul'da Lâtinler'in Bizans İmparatorluğu'nu ele geçirmeleri ile, Andrinikos Komnen soyundan Aleksiyos da Ereğli'den Kafkasya'ya kadar uzanan bölgede ve merkezi Trabzon olmak üzere bir Rum imparatorluğu kurmuş; kardeşi David Komnen ise Kastamonu ve Bolu taraflarmı ele geçirmiş bulunuyordu. Her iki kardeş vaktiyle dedelerine ait olan Amasya'yı da ele geçirmek ve Selçukluları pursatmak için 1210 'da Amasya'yı zorlamağa başlamışlardı. Buna rağmen 1214 yılında Selçuk sultanı I. İzzeddin Keykavus tarafından Kastamonu ve dolaylarına hücum edildiği, sinop'un zaptedildiği Trabzon İm-

${ }^{36}$ Bk. Türkiyede Meshûn Yerler Kılavuzu, İçişleri Bakanlı̆̆ yayınlarından Seri: II, Sayı:2, Cilt I, Ankara Başbakanlık Devlet Mtb. sah. 289.

${ }^{37}$ Bu konuda daha ayrunth bilgi almak için bk. Mü krimin Halil Yinanç, Danişmendliler md. İslâm Ansiklopedisi, C. III, sah. 476-477. 
paratorluğunun da vergiye bağlandığı tarihî kaynakların verdiği bilgilerdendir. Bu harpte Kastamonu'nun Selçuklular eline geçtiğine dair kesin bir kayıt yok ise de, Kastamonu tarihi üzerinde araştırmalar yapan Talât Mümtaz Yaman, bir yazma eserin iç kapağına H. 610 (M.1213) yılını Kastamonu fethi için ebced hesabı ile tarih düşen bir ibareden bahsetmektedir ${ }^{38}$. Kastamonu ve yöresi bu yıllarda daha Selçuklular eline geçmemiş olsa bile, biz I. İzzeddin Keykavus'un 1219 yılında ölümünden sonra yerine geçen kardeşi I. Alâeddin Keykubat devrinde, Kastamonu ve yöresinin Selçuk emirlerinden Hüsameddin Emir Çoban'a bir atabeylik olarak verildiğini ve burada Çobanoğulları beyliğinin kurulduğunu görmekteyiz. Bu beylik Kastamonu ve yöresinde 1292'de Candaroğulları beyliğinin kuruluşuna kadar devam etmiştir.

Çobanoğulları devri, Kastamonu ve yöresinin etnik yapısında önemli gelişmelerin meydana geldiği bir devir olarak kabul edilmelidir. D a nişmendli'ler devrinde, B i z a n s l 1 l a r ile Türkler arasında, bu bölgenin o zamanki türkleşme durumunu tehlikeye düşürecek kadar el değiştirmiş olan Kastamonu ve yöresi, Çobanoğulları devrinde Türk etnik unsurlarının yerleşmesi bakımından çok daha durulmuş bir devreye girmiştir.

II. Murad devri tarihçilerinden Yazıcızâde Âli, II. Murad için yazdığı "Selçuknâme" adlı eserinde, Hüsameddin Emir Çoban'ın Kayı'lardan olduğunu kaydetmiştir ${ }^{39}$. Ancak, bu yazara kaynaklık etmiş olan İbni Bībỉ'nin Selçuknâme'sinde böyle bir kayıt bulunmadığından, Emir Hüsameddin Çoban'ın kayılardan olduğuna dair verilen bilginin doğrudan doğruya Yazıcızâde tarafından eklenmiş olduğu yargısına varılmaktadır. Bu durum Osmanlılar'in menşei gibi, Çobanlar'ın menşeini de Kayı'lara bağlamak noktasında verilen bilginin bazı tarihçilerce kısmen şüphe ile karşılanmasına yol açmıştır ${ }^{40}$.Bununla birlikte Yazıcızâde tarafindan verilmiş olan bilgi tarihçiler arasında genel olarak benimsenmiş bulunmaktadurit ${ }^{41}$

Gerçi, bugün için yalnız Çobanoğulları devri değil, An a dolu Selçukluları'nın kuruluşuna ve Anadolu'nun fethine Oğuz boylarından hangilerinin katılmış olduğu ve Anadolu Selçuk imparator-

${ }^{38}$ Bk. Kastamonu Tarihi, sah. 80.

39 Selçuknâme, Topkapı Sarayı, Revan Ktp., no: 1390, yayım: T. Houtsma, Leiden 1932, C. III, sah. 208.

40 Bk. F. Sümer, Kayı mad. İslâm Ansiklopedisi, C. II, sah. 461.

${ }^{41}$ Bk. A. Tevhid, Rum Selçukî Devleti'nin Inkirazı ile Teşekkül Eden Tavaif-i Mülûk, Tarih-i Osmanî Encümeni Mecm. yıl 1326. cüz 5. 
1 uğu'nun dağılmasından sonra kurulan beyliklerin etnik yapısı konusundaki bildiklerimiz de pek az ve şüphelidir. Bu hususta kaynaklarm bırakmış olduğu boşluklar, 16-ıneı yüzyıl ve sonrasına ait arşiv kayıtlarının verdiği deliller, istidlâller ve bir de yer adları incelemeleri ile kısmen doldurulmağa çalışılmaktadır. Bizce, bu alanda yapılan çalışmalardaki tarih ölçülerine, yerleşme yerleri ile, bağh bulundukları boylar bilinen $\mathrm{Oğuz}$, Türkmen v.b. unsurların ağızlarına ait karşılaştırmalı çalışmalardan alınacak sonuçların da katılması gerekir. İşte bu temelde elde edilen bilgiler ile, Selçuklular devrinde Anadolu'daki yayılış alanları AnkaraKastamonu arasında bulunan otuz bin çadurlı Türkmen gurubu arasında büyük bir kayı kolunun bulunduğu, Ankara ve Kastamonu bölgesinin Emir Hüsameddin Çoban'ın malikânesi olduğu yolundaki tesbitler ${ }^{42}$, Kastamonu ile Bolu arasındaki bölgede Kayı boyuna giren $\mathrm{Oğuz} \mathrm{unsurlarmm} \mathrm{da} \mathrm{yer-}$ leşmiş olduğunu göstermektedir. Bu gerçeği 16-ıncı yüzyıl Kastamonu defterlerinde Kayı, Kayılu adını taşıyan köylerin bulunmuş olması da az çok desteklemektedir ${ }^{43}$. Öyle ki, bu köylerden biri ve büyükçesi de, doğrudan doğruya iskân tarihi bakımından Bartın ilçesini beslemiş olan Daday bucağına bağhı bulunmaktadır. Bunların dışında, Çobanoğulları devri için belirtmek istediğimiz başka bir nokta da, Emir Çoban ister Kayı'lardan ister Oğuzlar'ın başka bir kolundan gelmiş bulunsun, Çobanoğulları devrinde Emir Çoban'a bağlı aşiretler dolayısiyle Kastamonu ve yöresine etnik yapı ve ağız özellikleri bakımından $\mathrm{Oğuz}$ diye nitelendirebileceğimiz bir kısım Türk unsurunun yerleşmiş olduğudur. Biz, Bartın ve yöresi ağızlarındaki, yer yer Anadolu'nun batısında kalan bazı ağızlar ile de birleșen, alt ve temel tabakayı kuran özelliklerin bu ilk yerleşme devrinden geldiği kanısındayız. Esasen durum bütün Anadolu ịçin aşağı yukarı böyledir. Bu bölge ağzına daha sonraki yerleşmelerden geçmiş olan özellikler, bu makalenin girişinde ve 10-uncu notta belirttiğimiz üzere, ağız bakımından Türkmen niteliği göstermektedir.

§ 7. Çobanlar ve onu takibeden devre ait tarihî olayların gözden geçirilmesi, Kastamonu ve yöresinin Kıpçak unsurları ile olan münasebetlerine dair de bir-takım bilgiler ortaya koymaktadır. Hattâ bazı görüşlere dayanmak gerekirse, Kastamonu ve yöresinin $\mathrm{K}_{1}$ p çak unsurları ile olan ilgisini belki Çobanlar'dan daha önceki devirlere kadar bile götürmek mümkündür.

${ }^{42}$ Bk. F. Sümer, Osmanlı Devrinde Anadoluda Kayılar, sah. 590; Ebü'l-Fida, Takvim -al-buldân, yayın: Ch. Schier, Dresden, 1846, sah. 210.

${ }^{43}$ Tapu Kadastro Genel Müdürlüğü Arşivi, Defter-i Mufassal-ı Kastamonu, no: 143, sah. 148 Kayılu, sah. 321 Káyz. 
Zeki Velidî Togan, birer ihtimal olarak kullanılabilecek bazı ipuçlarına; özellikle Strabon'da Pontus ve Kapadokya Komanası ilâhlarmın Kırım İskitleri'nden gelmiş gösterildiğine dair kayıtlara, Kumani ve Komana kelimeleri arasındaki benzerliklere dayanarak, İskitler ile Pontus ve Kapadokya'daki (Kastamonu ve yöresi) Küçük-Asya Komanası arasında Tür k menşeine bağlazan bir ilgi bulunduğunun farzedilebileceği düşüncesindedir ${ }^{44}$. Bir-takım tarihî olayların Kuman-Kıp̧̧ak Türk kavimleri üzerinde bir silindir vazifesi görerek, onları tarih ölçüsünde kısa sayılabilecek bir zaman içinde, islâvlaştırmak ve hristiyanlaştırmak suretiyle ${ }^{45}$ nasıl ezip erittiği gözönünde bulundurulursa, bu şekildeki etnik menşe birliği faraziyelerinin üzerinde durduğumuz ağız araştırmaları bakımından her hangi bir değer taşıyamıyacağı kendiliğginden anlaşılır. Ancak, 13-üncü yüzyıl ortalarına kadar Anadolu içinde kendini gösteren Türk-Bizans münasebetleri bakımından Kıpçak ve Kuman unsurları üzerinde durulabilir. Bizans kaynaklarında, Anadolu'da yayılma seyri içinde bulunan göçebe Türklerin siyasî sınır tanımıyan taşmalarına ve Türk uç beylerine karşı, kendilerinin de aynı sistemle sınır bekçileri koyduklarını gösteren bilgilere rastlanmaktadır. Böyle bir tedbir olmak üzere Bizans imparatoru J. Vatatzes'in (1222-1254) hristiyanlaştırılmış onbin gö ç e be T ürk unsurunu Trakya'dan Anadolu'ya aktarıp, Menderes vadisine ve Frikya'ya yani, B i z a n s lı l a r ile T ü r k l e r arasmdaki sını boylarma yerleştirdiği bilinmektedir ${ }^{46}$. Theodor Laskaris II. babası için yazdığı methiyede, Vatatzes'in, Türklerin batıya doğru olan önüne geçilmez hamlelerini, Kumanları bulundukları batı bölgesinden doğuya aktarmak suretiyle yatıştırmış olduğunu naklediyor ${ }^{47}$. Bizans İmparatorluğu'nun 13-üncü yüzyıl ortalarından daha sonraya kadar koruna gelen hudutlarının, Pontus kıyısında Sinop'un batısında kalan bir noktadan başlayıp; Kastamonu, Kütahya ve Denizli'yi Selçuk Sulta nlığı'nın. emniyete alınmış noktaları olarak gerisinde brrakan bir kavis içinde devam ederek Akdeniz'de Makri. körfezine kadar uzandığı ${ }^{48}$ göz önünde bulundurulursa, Bizanslılar'm 13-üncü yüzyılın ilk yarısında doğuda Türkler'e karşı sınır bekçisi olarak

${ }^{44}$ Bk. Zeki Velidî Togan, Umumî Türk Tarihine Giriş, C.I, İsmail Akgün Mtb. İstanbul 1946, IV. Bölüm, sah. 450, not 305.

${ }^{45}$ Bu konuda ayruntılh bilgi için bk. R. R a hmetî Arat, Kıpçak mad., Islâm Ansiklopedisi, C. VI, cüz 62, sah. 713 ve öt,

${ }^{46}$ Nic. Gregoras, I. sah. 37 B, Cantacuzen I, sah. 18 B ve buradan naklen P. Wittek, Menteşe Beyliği, sah. 13.

${ }^{47}$ Bk. Moutavt S e h e v, aym yerde, sah. 76 not 2 'den alınarak, P. Wittek, Menteşe Beyliği, sah. 13

${ }^{43}$ Bk, P. Wittek, Menteşe Beyliği, sah. 1. 
kullanılmak üzere Menderes vadisine ve Frikya bölgesine yerleştirmiş oldukları Türk-Kuman unsurlarınm kısmen Kastomonu'nun batı kesimine düşen bölgede yer aldığı anlaşılır. Bundan başka Çobanoğulları devrindeki bazı siyasî gelişmeler, doğrudan doğruya $\mathrm{K}$ a s t a m o n u B e yli ğ i ile K arasındaki münasebete dayanmıştır İbn-i Bĩbĩ, El-evâmirü'lAlâiyye fi'l umûri'l-Alâiyye adlı eserinde, Selçuk sultanı I. Alâeddin Keykubat'in emri ile, "emirüllümera" diye adlandırılan, S elçuk emirlerinin en eski ve itibarlılarından olan Hüsameddin Emir Çoban'm Deșt-i Kıpçak'a yapmış olduğu seferi uzun uzadıya ele almıştır ${ }^{49}$. Hüsameddin Emir Çoban idaresinde Karadeniz'i geçerek Kıpçak eline ulaşan Türk ordusu, bu seferde Kıp çaklar elindeki Suğdak'ı aldığı gibi, daha ileride Rus melikini de vergiye bağlamıştır. Kıpçak-ili'nin ve buradaki hristiyan Türklerin tavsifini veren İbn-i Bĩbĩ, Emir Çoban'ın bu seferden elde ettiği sayısız köle ve ganimetle$\mathrm{ri}^{50}$ atabeyliğinin merkezi olan Sinop ve Kastamonu'ya gönderdiğini kaydetmektedir $^{51}$. Kastamonu Atabeyliği ile Deșt-i Kıpçak arasındaki münasebetler Selçuk sultanı İzzeddin Keykavus II ile Kılıৎ Arslan IV arasındaki mücadeleleri aşan daha sonraki olaylarda da yer almıştır. Kaçmiş olduğu Bizans'tan Kipȩak ham Menkü Timur han eliyle kurtarlan İzeddin Keykavus'un Berke Han'ın kızından olan oğlu Gryaseddin Mes'ud II ile Rükneddin Kılı̧ Arslan arasındaki kardeş mücadelesi Kastamonu ve Amasya bölgelerinde geçmiştir. Bilindiği gibi, babasının ölümünden sonra Anadolu'ya gelmeğe karar veren Gıyaseddin Mes'ud, Deşi-i Kıpçak'tan, yanına aldığı kimseler ile birlikte ilkin Sinop yolu ile Kastamonu'ya çımıştır. $\mathrm{O}$ zaman Kastamonu beyi Hüsameddin Emir Çoban'ın oğlu Muzafferüddin Yavlak Arslan'dur. Gıyaseddin Mes'ud'un gelişi üzerine, Muzafferüddin Yavlak Arslan kendisine bağlllık göstermiş ve atabeyi olarak yine Kastamonu'da kalmıştır. Gıyaseddin Keyhusrev III. 'ün ölümün-

${ }^{49}$ Bk. Tıpkıbasım I. Önsöz ve fihristi hazırlayan: A d n an S a d ık Erzi, TTK. yaymlarından I, Seri no: 4a Ankara TTK. Basm., 1956, sah. 300-307, 307-310. ve öt. Ayrica Anadolu Selçukî Devleti Tarihi, İbn-i B ì b I'nin Farsça Muhtasar Selçukname'sinden Türkçeye aktaran M. N u ri G en c os m a n, Ankara Uzluk Basm. 1941 sah. 118-127.

${ }^{50}$ Bk. not $49^{\prime}$ da gösterilen I bn-i Bỉbĩ mufassalr, tıpkıbasım sah. $328-330$, Yazıcızâde 'Alĩ, Tãrỉh-i Âli Selçuk, M. Th. Houtsma yaymı, leiden 1902, sah. 353; M u ḩ t a ş a S e l çu knāme, M. Th. H o u t s m a yaym leiden 1902, sah. 136; M. Nuri Gencosman yaym sah. 124; Duda yaym (Die Seltschukengeschichte der İbn-i Bibi Kopenhagen, 1959), sah. 138.

${ }^{51}$. Bk. I b n-i Bỉbi mufassah sah. 323; Y az c c izâde, M. Th. Houtsma yayım sah. 344, 345; M u ht a sa r S e lęuknāme, M Th. Houts ma yayın, sah. 134, D u d a yaymı sah. 136. 
den sonra İlhan Geyhatu'nan desteği ile onın yerine Selçuk sultanı olan Giyaseddin Mes'ud II, o zaman kendi saltanat merkezi olan Amasya' da bulunuyordu. Bu sırada Kastamonu'lular da başlarma Kırım'dan gelen Gıyaseddin Mes'ud'un kardeşi Keyumers Kılı̨ Arslan'ı geçirmişler; onu sultan olarak tanıarak Illh an'a isyan etmişlerdi. Bunun üzerine durumu tehlikeye düşen Gryaseddin Mes'ud II ve İlhan Geyhatu Kastamonu Atabeyi Muzafferüddin Yavlak Arslan'ı, çarpışmak üzere Keyumers üzerine göndermişlerdir. Muzafferüddin Yavlak Arslan 1292 ylında yapılan bu çarpışmada Keyumers tarafindan öldürülmüştür. Bundan sonra Giyaseddin Mes'ud II'nin Keyumers ile bizzat yaptığı savaş da yınilgi ile sonuçlanmış ve tehlike ancak İhan Geyhatuya yardımcı olarak gelen Şemseddin Yaman Candar'ın araya girmesi ile atlatılabilmiştir ${ }^{52}$.

İşte bu siyasî olaylar, bize, Kastamonu ve yöresi ile Deşț-i Kıpçak arasında birtakım münasebetlerin geliștirilmiş bulunduğunu göstermektedir. Öyle ki, bu münasebet yalnız bir siyasî münasebet olarak kalmamış daha -sonraki devirlerde de süregelen bir ticarî münasebet olarak da hayli gelişmiştir. AlUmarî, Masâlik al-Absâr'ında Candaroğulları devrindeki K a s t a m o n u B e y li ğ i'nden bahsederken bu bölgenin Kırım, Kıpçak, Bulgar, Rus ve hattâ Mısır ile olan deniz ticaretinin önemini de belirtmektedir. Sinop'tan söz açarken, buranın Kıpçak(Suğdak)alanına en yakın bir bölge olduğunu özellikle kaydediyor. Mısır M e ml ûkleri ile olan münasebet konusunda "merkezi Kastamonu olan bu memleketin bizim Misır sultanları ile aralarında sıkı bağlar vardır" demektedir ${ }^{53}$. Kastamonu ve Bartın bölgesinin Mısır ile olan münasebetinden 17-inci yüzyılda Evliya Çelebi bile bahsetmektedir. Evliya Çelebi H. 1050 tarihinde yaptığı Karadeniz gezisi dolayısiyle "Bartın nehri, azim bir nehirdir. Misır gemileri yüklenip giderler" ${ }^{54}$ diyor ki, bu kısa bilgi Kastamonu dolaylarının Mısır Memlûkleri ile olan ticarî münasebetinin 17-inci yüzyıla kadar devam ettiŏini göstermektedir. Moğol devri Önasya'sı ile Mısır'ın iktisadî münasebetlerini inceleyen A.N. Poliak, Mısır'daki Kıpçak Memlûkleri ile Deşt-i Kıp̧̧ak arasında çok sikı siyasî ve kültürel münasebetlerin kurulmuş olduğunu tesbit etmiştir ${ }^{55}$. Zeki Velidî Togan ise,

${ }^{52}$ Bu olayların ayruntıları için Bk. Kastamonu Tarihi sah. 80-84; K e r im ü ddin Mahm ud,Müsâmeret ül-Ahbâr, O s m an Turan yaym, Ankara 1044. TTK. yaymı sah. 133-134, 137, 168, 170-173, 206, 294 v.b. ; Camiüddüvel sah. 1184.

${ }^{53}$ Bk. F. Taeschner yayın, sah. 40.

54 Bk. Cilt II, sah. 71 .

${ }^{55}$ Le caractere colonial del'Etat Mamlouk dans ses rapports avec la Horde d'ord. Revue des Etudes Islamiques, IX, 1935, P. 231-248. 
Canik, Sinop, Kastamonu ve Marmara kıyılarındaki ilk Türk-İslâm kolonilerini Mısır Memlûkleri ve Deşt-i Kıpçak ile olan münasebetlerde düğüm noktalan olarak kabul etmiștir ${ }^{56}$. Bu konuda, Kastamonu'daki Çobanoğulları zamanında Kefe ile Kastamonu'ya bağlı Anadolu kıyı bölgeleri arasında kayıkȩılık yapıldığı ve deşt-i Kıpçak'tan Anadolu'ya onbin hanelik Kıpçak Terakimesi'nin geldiği yolunda Timurîler devrine kadar ulaşan bir rivayeti de ${ }^{57}$ yabana atmamak gerekir.

Yukarıda Bartın ve yöresi ağızları için tesbit etmiş olduğumuz Kıpçak dil özellikleri ile, Kastamonu ve yöresini Kuman-Kıp̧̧ak ve MemlûkKıpçak unsurlarına bağlayan siyasî ve ticarî gelişmeler gözönünde bulundurulursa, ba gelişmeler sırasında Kastamonu ve yöresine, özellikle Bartın

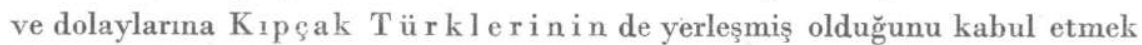
gerekir. Gerçi, bilindiği gibi tarihî kaynaklarda yalnız siyasî olaylar anlatılmakta, bunlara bağlı etnik gelişmelere dair açık bilgiler verilmemekte ise de, yukarıda açıladığımız türlü tarihî, siyasî ve ticarî münasebetlerin ortaya koyduğu sonuçların bugünkü dialcktoloji malzemesi ile karşılaştırılması, bu bölgeye "siyasî ve iktisadì gelişmelere paralel olarak çok sayıda Kıpçak unsurlarının da yerleşmiş olduğundan şüphe ettirmemektedir. Bundan başka kişi ve yer adları üzerindeki bazı tesbitler de bu gerçeği desteklemektedir. Hüseyin Hilmi, Sinop Kitabeleri adh eserinde Sinop'ta Emir Beklemiş b. Emir Taybuga b. İlbasmış b. Koçkar b. Ogulbek. b. Beşbek'in, üzerinde H. 679 (M.1280) yılını taşıyan türbesinin bulunduğunu bildiriyor ${ }^{58}$. Türk dili ile uğraşanların bildikleri ve Z.V. Togan'ın da işâret ettiği üzere, -mış/-miş isim-fiil ekleri ile yapılmış İlbasmış, İltutmuş, Beklemiş ve ayruca Beşbek gibi adlar Kıpçaklar arasında yaygın olan adlardandır ${ }^{59}$. Bolu-Bartın ve Bartın-Kastamonu-Sinop arasinda uzanan bölgedeki yer adları arasında Borlu : Taraklı-borlu ${ }^{60}$, Karye-i Borköy ${ }^{61}$ Kara-togan ${ }^{62}$, Kara-togan Ocağ $\beth^{63}$,

${ }^{56}$ Bk. Z. V. Tog a n, Umumi Türk Tarihine Giriş, sah. 310.

${ }^{57}$ Bk. Z. V. Togan, Umumi Türk Tariline Giriş, sah. 312.

${ }^{58}$ Sinop Kitabeleri, Sinop 1341, sah. 33; buradan aktararak Z. V. Togan, Umumî Türk Tarihine Giriş, sah. 310 ve not. 24.

${ }^{59}$ Kıpçaklardaki İlbasmış şekli için bk. L. Rasonyi, d. Etudes sur L'Europe Centre-orientale, III, Budapest 1936, sah. 29-30 ve A. Kâşânî, yp. 139 b.

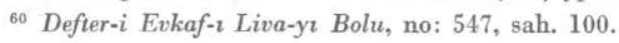

${ }^{61}$ Not 59'da göst. defter, sah. 182 b.

${ }^{62}$ Not 59'da göst. defter, sah. 182 b; Defter-i Mufassal-ı Bolu, no: 35, sah. 384.

${ }^{63}$ Defter-i Mensuhat-1 Mufassal-i Bolu, no: 123, sah. 94 b. 
Karye-i Alpagut ${ }^{64}$, Alpu $^{65}$, Kizll-saray ${ }^{66}$ Sarayct $^{67}$, karye-i Taybuga ${ }^{68}$ gibi Kıpçak niteliğini taşıyan köy adları da vardır. Bütün bu durumlar bu bölgelere Kıpçak unsurlarmin yerleşmiş olduğunu, tarihî kaynaklarmn vermiş oldukları bilgilerdeki nisbî bulanıklı̆̆ silecek ve ağızlar malzemesinden elde ettiğimiz sonuçları doğrulayacak şekilde ortaya koymaktadır.

\section{Candaroğulları Devri}

§ 8. Kastamonu ve yöresi tarihindeki üęüncü devir Candaroğulları devridir. Candaroğulları, yukarıda bir ara dokunduğumuz gibi, Selęuk sultanlarından Mes'ud II'nin Kastamonu'da hükûmete kalkışan kaıdeşi Rükneddin Keyumers'e karşı açtığı savaşa yardımeı olarak gelen Şemseddin Yaman Candar'ın kurduğu bir beyliktir. Keyumers'in yenilmesi ve Atabeyi Muzafferüddin Yavlak Arslan'ın öldürülmesi üzerine, Illhan Geyhatu bu harpteki hizmetine karşllı olarak Şemseddin Yaman Candar'a Kastamonu ve yöresini vermiş bulunuyordu. Candaroğulları'nın ilk devirlerinde beylik merkezi Eflâgun (Eflâni) idi. Çünkü, Şemseddin Candar, babası Yavlak Arslan'ın öldürülmesinden sonra yerine geçip ken-• disine direnen oğlu Mahmud Beye karşı bir şey yapamadığı için bir müddet Eflâni ve yöresi ile yetinmek zorunda kalmıştır. Beylik merkezinin Eflâni'den Kastamonu'ya aktarılması Şemseddin Yaman Candar'ın oğlu Süleyman Paşa zamanındadır. 1292 yılında kurulan bu beyliğin Kastamonu şubesi, Osmanlı sultanı Yıldırım Bayezid'in Kastamonu'yu alış tarihi olan 1392 yılına kadar sürmüştür. Ancak, beyliğin Sinop şubesi beyi bulunan İsfendiyar Bey, Osmanlı hanedanındaki karışılık ve saltanat kavgalarından yararlanarak, beyliğe dahil başka yerler ile birlikte Kastamonu'dan Bolu'ya kadar olan yerleri de zaman zaman yeniden beyliğinin topraklan içine katmış olduğundan, Candaroğulları beyliğinin büsbütün ortadan kaldırılması ancak Fatih Sultan Mehmed devrinde gerçekleşebilmiştir ${ }^{69}$.

${ }^{64}$ Defter-i Mufassal-ı Kastamonu, no: 143, sah. 33, 123.

${ }^{65}$ Not 63 'te göst. defter, sah. 115.

${ }^{66}$ Not 63 'te göst. defter, sah. 143 b: tâbi-i nahiye-i Araç.

${ }^{67}$ Not 63 'te göst. defter, sah. 85b; no: 200, sah. 106 b.

${ }^{68}$ Defter-i Mufassal-ı Kastamonu, no: 200, sah. 95 b: tâbi-i nahiye-i Sinob.

${ }^{69}$ Candaroğulları Beyliği’nin siyasî hayatı üzerine geniş bilgi almak için bk. 1.H. Uzunçarşılı, Anadolu Beylikleri ve Akkoyunlu Karakoyunlu Devletleri, TTK. yayınlarından VIII, Seri-2, Ankara 1937, sah. 23-26; İslam Ansiklopedisi 52-inci cüz Isfendiyaroğulları mad.; T.M. Yaman Kastamonu Tarihi, sah. 95-170: Candaroğullar ve bu bölümde verilen bibliyografya. 
Eldeki tarihî kaynaklar Candaroğulları Beyliği'nin etnik yapısını aydınlatacak bilgiler vermemektedir. Genel olarak bir "Türkmen beyi" diye gösterilen ${ }^{70}$ Şemseddin Yaman Çandar'ı, yalnız Amasya Tarihi yazarı Hüseyin Hüsameddin, yararlandığı kaynağı da göstermeksizin Alayuntlu Türkmen aşiretine bağlamıştır. Bu yazara göre, Candaroğulları ailesi, asıl Arslan Bey adl bir beyden, Arslan Bey de Alayuntlu Türkm en oymağından gelmektedir ${ }^{71}$. Anasya Tarihi'ndeki bu bilgiye dayanarak, Kastamonu Asar-ı Kadimesi yazan M. Behçet de Şemseddin Emir Candar'ın Kastamonu'yu, Alayuntlu aşiretini yanına alarak zaptetmiş olduğunu kaydetmiştir ${ }^{72}$. Hüs eyin $\mathrm{Hüsameddin'in} \mathrm{verdiği} \mathrm{bilginin}$ kaynağının gösterilmemiş olmasını gözönünde bulunduran Prof. Dr. Faruk Sümer de haklı olarak, Kastamonu bölgesinde Alayuntlu boyuna bağlı 20 hanelik küçük bir oymağın yaşamasına rağmen ${ }^{73}, H$. Hüsameddin'in ifâdesi tevsik edilmedikģe Alayuntlu boyu ile Cándar ailesi arasında kavmî bir münasebetin bulunduğuna dair görüş ileri sürülemiyeceğini belirtmiştir ${ }^{74}$. Biz sayın Faruk Sümer'in bu görüşüne esas itibariyle katılmakla birlikte, arşiv defterlerindeki kayıtlara dayanarak, Kastamonu, Bartın ve yöresini Candaroğulları topraklarına bağlayan devirlerdeki gelişmeler sırasında, bu bölgeye Alayuntlu'lardan olmasa bile, başka Türkmen zümrelerinin gelip yurt tutmuş oldakların belirtmek isteriz. Bu durum, Candaroğulları beylerince köylerde türlü kimselere vakıf olarak verilen yahut İsfendiyar, Kasım v.b. beylerin mülkiyetinde bulunan toprakların, çoklukla Avşar, Avşar Divanı, Kınık, Emir Salar, Eymir v.b. Türkmen köylerine düşmesi ile de desteklenmektedir. Bunun dışında Bartın ve yöresi ağızlarında T ü r k m e n dil özelliklerinin çok canlı bir şekilde devam ettirilegelmiş olması, Candaroğulları devrinde Bartın ve yöresi kesimlerine ağız yapısında bir üst tabaka kuracak şekilde, yoğun Türkmen unsurlarının yerleştiğini göstermektedir. Bununla birlikte bölg€dəki Türkmen unsurlarının buralara yalnız Candar oğulları devrinde gelmiş olduklarını iddia şeklinde bir düşüncemiz de yoktur. Bunlar, kısmen Candaroğulları'ndan önceki devirde gelmiş olabilecekleri gibi, Bartın'ın ilçe hâlində gelişip genişlemesine paralel olarak Eflâni, Safsah. 23 .

${ }^{70}$ Bk. I.H. Uzunçarşılı, Anadolu Beylikleri ve Akkoyunlu Karakoyunlu Devletleri,

7 Bk. Amasya Tarihi, C. II, sah. 432, not I.

72 Bk. Kastamonu Asâr-ı Kadimesi, İstanbul 1341, sah. 25.

${ }^{73}$ Bk. Başb. Arşivi, no: 327 Kastamonu Defteri, yp. 44 a.

${ }^{4}$ Bk. Osmanlı Devrinde Anadolu'da Yaşayan bazı U̧̧̧oklu Ouz Beylerine Mensup Teşekküller, Ístanbul Úniv. Iktisat Fakültesi Mecm. XI (1952), sah. 468. 
ranbolu, Ulus bölgelerinden daha sonra Osmanlılar devrinde de gelmiş olabilirler. Bartın ve yöresinin bu devre ait gelişmesini yukarıda 3-üncü paragrafta açıklamağa çalışmıştık.

16-ıncı ve 17-inci yüzyıla ait arşiv defterlerindeki kayıtlardan ve köy adlarından, Kastamonu ve yöresine Alayuntlu'lardan başka, Avşar, Kınık Yiva, Kara-evlü, Çavundur, Cebelü, Evciler, Eymür, Eriklü Kozanlı, Dodurga, Çepni gibi Türkmen oymaklarmm da geldiği anlaşılmaktadır. Gerçi, bazı durumlarda köy ve yer adlərının yalnız belirli boy ve oymak şeklindeki etnik zümrelere izafeten değil, o zümrelere ait adlarn kişi adı olarak almış bulunan kimselere izafeten de verilmiş olması, bu köylerdeki halkın, o adları taşıyan boylardan gelip gelmediği konusunda uyanık olmayı gerektirmekte ise de, gerek bu bölgeye ait dil malzemesinin taşıdığı özellik, gerek Anadolu'nun aynı adları taşıyan başka bölgelerindeki köyler ağızlarının bu köyler ağızları ile gösterdiği uygunluk ve yakınlık, yukarıda sayılan köy adlarının, şahıslardan değil, o adı taşıyan boy ve oymaklardan gelmiş olduğu konusunda şüphe bırakmamaktadır. Yine arşiv kayıtlarından Kastamonu ve yöresinde, eski devirlerde henüz yerleşik hayata geçmemiş Yörük cemaatlerinin bulunduğu da anlaşılmaktadır. H. 990 tarihli ve 143 sayıl Defter-i MufassalKastamonu'da Araçilçesine bağlı olmak üzere Göneciyan-1 Cedid (s. 194 b), Kara-gözlü ve İhsanlu (s. 200 b, 201 a), Kuzgunlu (s. 202 a,b), Çiyülü (sa. 203), Köse-Halil (s. 203 b), Resuller yahut Kaya-başı (s. 204 a), Menteşe Fakih öteki adı ile Aşıklu, Saltıklu (yahut Saltuklar ?), Ali-Beyli (s. 206, 207); Daday'a bağlı olarak da Sofucalar (s. 345 b, 115 hane) Yörük cemaatlarının adları geçmektedir. Yine 990 tarihli ve 176 no'lu Kastamonu Defteri'nde Taşlöprü bucağına bağh olan Eriklü (s. 86 b, 78 hane), Akȩa-kavak öteki adıyle Dede Fakihlü (s. 28, 28 hane), Çallu (s. 87, 33 hane), Çötüller (s. 87 b, 44 hane), Kozanlu (s. 87 b, 9" hane), Ali Hacılu (s. 88 a, 58 hane), Yeleklü, Çoğaçlu (s. 88 b) cemaatları saysliyor.

Bütün bu kayıtlar 16, 17-inci yüzyıllardaki duruma göre, Kastamonu ve yöresinde, göçebe veya yerleşik hayata geçmiş birçok Türkmen unsurlarının bulunduğunu açıkça ortaya koymaktadır.

Eldeki arşiv kayıtlarından yararlanarak bir de Bartın ve yöresini elder geçirecek olursak, bu bölgeye Avşar, Kınık, Salur Türkmenlerinin yerleşmiş olduğunu kesin olarak söyleyebiliriz. Çünkü, Ankara Tapu Kadastro Genel Müdürlüğü Arşivi'ndeki 547 sayılı Evkaf-ı Liva-yı Bolu Defteri'nde “nahiye-i Oniki Divan'a bağlı köyler arasında Afşar, Avşar (s. 157 b, 159, 160 
b, 183 b), Kınık (s. 166); 123 saylı Mensuhat-ı Mufassal-ı Bolu Defteri'nde ise Kınıisu (s. 94 b), Salır-Beyi (s. 384 b'deki listede 58-inci köy), Emir-Salar

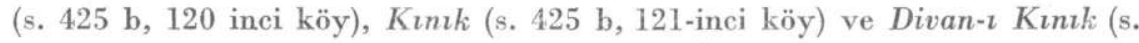
$420,423,424,425)$ adlarına rastlanmaktadır. Öyle ki, sonuncu defterde 102 , 103, 109, 111 ve 121-inci köylerin Oniki Divan veya Amasra kal'asına bağlı

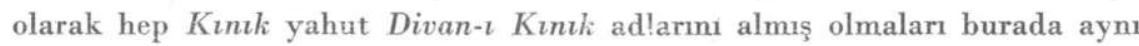
adı taşıyan bir-kaç Kınık köyünün bulııdığunu da ortaya koymaktadır. Bundan başka köylerdeki kimi toprak parçalarının yahut ekinliklerin Salur yeri $^{75}$, Eymür-Togan ${ }^{76}$ yeri v.b. adlar ile adlandırılmış olması da, buraların bu adları taşıyan $\mathrm{T}$ ü r k m e $\mathrm{n}$ bey ve boyları ile ilgisi olabileceğini hatıra getirmektedir.

Oniki-Divan nahiyesinin yukarıda saydıklarımız dışında kalan köy ve yer adlarına bakarak, buraya başka hangi Türkmen zümrelerinin gelmiş olduğunu tayin edemediğimiz gibi, eldeki arşiv kayıtlarından Bartın ve yöresine, Eflâni, Safranbolu ve Daday bölgelerinden sonradan gelmiş olan unsurların da etnik kimliklerini ksзin olarak bilememekteyiz.

$\S 9$. Kastamonu ve yöresi ile Bartın ve yöresinin tarihî devirleri üzerine yukarıdan beri yapageldiğimiz açıklamalar ile, bu bölgeye, Kastamonu'nun türkleşme tarihinden başlayarak ta Osmanlılar devrine gelinceye kadar geçirdiği süre içinde hangi Türk etnik zümrelerinin gelip yerleşmiş olduklarını göstermeğe çalıştık. Elde edilen tarihî bilgilerin, arşiv ve bölgeden alınan dil malzemesi ile karşılaştırilıp değerlendirilmesi, bu bölgeye gelmiş bulunan ve 3üncü paragrafta sözünü ettiğimiz Kıpçak unsurlarının, yoğun olarak özellikle Bartın ve yöresinde yerleşmiş olduklarını ortaya koymaktadır. Çünkü, türlü tarihî olayların ve değişik devirlerin yeni etnik unsurları bol bol getirdiği bir bölgede, K ıp çak lehçelerine ait belirli bazı özelliklerin bugüne kadar eritilmeden kalabilmiş olması, ancak bölgedeki Türk-Kıp çak unsurlarının dilin ses yapısı bakımından kendileriniöteki $\mathrm{Oğuz}$ - Türkmen unsurları arasında hâkim kılacak bir sayı yoğunluğuna sahip olmaları jle izah edilebilir. Aynı özellikler Bolu, Kastamonu ve yöresine giren öteki ağızlarda artık Bartın'da olduğu şekilde görülmemektedir.

Bartın ve yöresinin Avşar, Kınık, Salur (Salar) Eymür v.b. Türkmen uruğları ile olan ilgisini yukarıda belirtmiștik. Fakat, adı geçen köyler dışında İnpiri, Çakraz, Bostanlar, Aşağıköy v.b. ile, Arıt bucağı'na

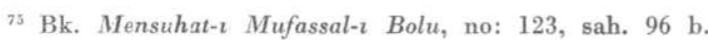

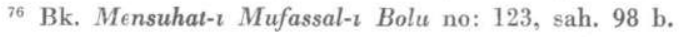


bağlı 17 parça köyde de Türkmen karakterini en açık bir şekilde yansıtan özelliklerin yer almış; daha doğrusu Bartın ve yöresinin T ü r k m e n lehçe yapısına ait özellikleri de kuvvetli bir şekilde vermiş olması, yukarıda adlarımı verdiğimiz Avşar, Kınık, Salur zümrelerinin Bartın ve yöresindeki başka köylere de yerleşmiş olduğuna yahut Kastamonu yöresinden yapılan sonraki aktarmalar da dahil olmak üzere, bölgeye daha başka Türkmen unsurlarının da gelmiş bulunduğuna delâlet etmektedir.

Bartın ve yöresinin, bugün bazı yönlerde Orta Anadolu, bazı yönlerde Çankırı, Bolu, Kastamonu, Denizli, Çivril, Tavas v.b. ağızlar ile kưmuş olduğu bağlantılar da, bu etnik durumla ilgili bulunmaktadır. Türlü Türk boylarının Anadolu'daki yayılma yerleri ile yayılma şekillerinin tesbiti, araştırma bölgemiz ile, aralarında bağlantı kurulan bu bölgelerin daha çok A vşar, Kınık, Eymir, Alayuntlu v.b. bazı Oğuz-Türkmen unsurları bakımından yakınlaştıklarını veya birleştiklerini ortaya koymaktadır ${ }^{77}$. Yalnız şu var ki, söz konusu etnik unsurların, her bölgede o bölgenin özel şartlarına uygun bir kaynaşma ve buna bağh birer gelişmeye uğramış

" Ebu'l-Fidâ, Takvim al-Buldân adlı eserinde Ibni Sa'id al-Magribî'nin Moğollar zamanında yazdığı bir coğrafya kitabında verilen bilgiye dayanarak, Selçuklular zamanunda Antalya kuzeyinden başhyarak Denizli ve Menderes bölgesinde 200.000 çadırłk Türkmen boylarının yaşadığ.n kaydediyor (bk. Ch. Schier yayım, Dresden 1846, sah. II; P. Wittek, Menteşe Beyliği, sah. 2). Aynı yazardan, Ankara ve Kastamonu arasında 30.000 çadurlkk bir Türkmen gurubunun daha bulunduğunu, Uludağ’dan Tarsus'a kadar uzanan Batı Anadolu'nun dağlık bölgelerinin bu eserde "Türkmen dağlan" diye adlandırıldığın, hattâ Ankara çevresinde Türkmen'lere bağh geniş bir Kayı kolunun da var elduğunu öğreniyoruz (gös. e. sah. 210; F. Sümer, Osmanlı Devrinde Anadolu'da Kayzlar, sah. 590; Z.V. Togan, Umumi Türk Tarihine Giriş, sah. 188). Kayıl a r'n Kastamonu-Bolu arasındaki bölge ile olan, yerlerinde belirttiğimiz ilgilerinden başka, 15 ve 16-1nc yïzyllarda, türlü şubeler halinde Konya, Isparta, Denizli, Muğla, Manisa, Afyon vẹ Ankara bölgelerinde de yayılmış oldukları tesbit edilmiștir. (bk. F. Sümer, Kayı mad., Istâm Ansiklopedisi, C. VI, sah. 460).

Avşarlar'm tarihi ve Anadolu'daki yayılma şekilleri de yukarndaki tesbiti doğruladığı gibi (bunun için bk. F. Sümer, Avşarlara Dair, Köprülü Armağanı, sah. 453-478), bunların Anadolu'nun nerelerine niçin ve ne şekilde yayılmıs olduklan noktasında beliren soruları da aydınlı̆ga çıarmaktadır. Eymir ve Alayuntlu'ların 16-ıncı yüzyıldaki yaylma alanlan için bk. F. Sümer, Osmanlı Devrinde Anadoluda Yaşayan Bazı Üł çoklu Oğuz Boylarına Mensup Teşekküller, Ist. Úniv. Iktisat Fakültesi Mecm. XI (1952), sah. 459-469 arası. Bunlardan başka Kayı, Kınık ve Avşar yer adlanın Anadolu'da bugün devam eden kalıntıları üzerinde yaptığımız incelemeler bile, bu üç Türk boyuna ait özellikler bakımından Afyon-Dinar, KütahyaUşak, Bolu, Cankırı, Kastamonu, Denizli-Acıpayam-Çivril, Zonguldak bölgelerini birer bakıma Bartın ve yöresi ağızlan ile birleştirmektedir. Bu hususu bundan önceki yazımızda belirtmeğe çahşmıştık. İşte yer adlan üzerinde yapılan bu şekildeki incelemeler ile, bu şekildeki birleşme. lerin sebepleri de az çok ortaya çımaktadır. 
olmaları, bu küçük ağız bölgelerini kendi araştırma bölgemizle, ancak belirli noktalarda birleştirmiş bulunmaktadır. Bartın ve yöresinin Kıpçak unsurlarından gelen özellikleri de yine bu esastaki gelişmelere dayanmaktadır ${ }^{78}$.

Demek oluyor ki Bartın ve yöresi ağızları eski bir Oğuz dil tabakası üzerine Kıpçak ve Türkmen unsurlarının getirdiği ağız özellikleri ile karışıp kaynaşarak, bu kaynaşmanın zaman içinde geliştirdiği özel bir kişilik altında oluşmuş bulunmaktadır. Kastamonu ve yöresi ile Bartın ve yöresi üzerinde yaptığımız tarihî devirlere ait etnik gelişmeler ile ilgili inceleme, bu üç ayrı ağız ve lehçe tabakasını içine alan karışma ve gelişmelerin Asya'da değil, doğrudan doğruya Anadolu'da, hattâ daha smurlayıcı bir deyimle söylersek Bartın ve yöresinde meydana geldiğini de ortaya koymaktadır. Öyle sanıyoruz ki, Bartın ve yöresi ağızları üzerine yayımladığımız birinci makalenin 3-üncü paragrafinda ortaya attığımız soru da, eldeki şu araștırma ile oldukça aydınlanmış, ve karşılı̆̆ını bulmuş olmaktadır.

${ }^{78}$ Bartın ve yöresi Ağızları adlı makalemizin 3-üncü paragrafında, Bartın ve yöresi ağızlarının, taşıdığı Kıpçak özellikleri bakımından Tebriz Azericesi, Azerice'nin Nahçıvan, Aynallu, Kaşkay ağızlan ve Afganistan'daki Avşarların dili ile ortaklaşan noktaları bulunduğunu bildirmiştik. Bu bölgelere ait tarihî gelişmelerin gözden geçirilmesi, Bartın ve yöresi gibi, Azerî bölgesinin de birinci derecede Türkmen, ikinci derecede peyderpey Kafkał ötesinden gelen Kıp̧̧ak unsurları ile kaplandığın gösteriyor. Bunların Tebriz ve Nahçıvan bölgelerinde daha yo šun olarak bulunmalan (bk. Z. V. Togan, Umumi Türk Tarihine Giriş, sah. 189) Azerice'ye bazı Kıpçak dil özelliklerinin aktarılması ile sonuçlanmıştı. 


$$
L
$$

